\title{
TINGKAT KEPUASAN MASYARAKAT TERHADAP KOLAM RENANG TELAGA RATU KOTA BARU PROVINSI JAMBI
}

\section{Level of Community Satisfaction towards Swimming Pool Telaga Ratu Kota Baru Provinsi Jambi}

\section{Boy Indrayana, Iwan Budi Setiawan}

${ }^{1}$ Program Studi Kepelatihan Olahraga, Universitas Jambi- 36361, Indonesia

Correspondence Author: boy indrayana@unja.ac.id Departement of Sport Science and Coaching, Universitas Jambi, Kampus Mendalo, KM 15 Jambi-Ma Bulian Street, Indonesia, 36361

\section{ARTICLE INFO}

Article History:

Received : October 30, 2019

Revised form : November 1, 2019

Accepted : November 23, 2019

Published online : November 24, 2019

\section{Kata kunci: \\ keyword 1; Kepuasan pelanggan keyword 2; Kolam telaga ratu keyword 3; Fasilitas olahraga}

\section{Keywords:}

kata kunci 1; Costumer satisfied kata kunci 2;Telaga Ratu swimming pool

kata kunci 3; sport facility

\section{ABSTRAK}

Kepuasan pelanggan merupakan hal yang sangat penting untuk meningkatkan pengunjung kolam renang Telaga Ratu. Perbaikan fasilitas seperti perluasan lahan parkir, menambah jumlah kamar mandi dan kebersihan air menjadi pendorong kepuasan pelanggan. Tujuan penelitian ini adalah untuk mengetahui tingkat kepuasan pelanggan kolam renang Telaga Ratu Kota Jambi. Penelitian ini adalah deskriptif kuantitatif dengan metode survey dengan pengambilan data menggunakan angket. Populasi penelitian ini adalah pengunjung kolam renang Telaga Ratu, sedangkan sampel dalam penelitian ini menggunakan 80 responden yang diambil dengan metode Insidental sampling. Hasil uji coba instrumen dari 38 butir pernyataan, gugur 9 butir pernyataan dan diperoleh 29 butir pernyataan valid dan reliabilitasnya sebesar 0,911 yang dihitung dengan program SPSS versi 16 . Teknik analisis data menggunakan analisis deskriptif persentase. Hasil dari penelitian tingkat kepuasan pelanggan kolam renang Telaga Ratu Kota Jambi yaitu (1) faktor kualitas produk masuk kategori memuaskan dengan persentase $76,25 \%$, (2) faktor harga masuk kategori memuaskan dengan 52,5\%, (3) faktor kualitas pelayanan masuk kategori memuaskan dengan $81,25 \%$, (4) faktor emosional masuk kategori memuaskan dengan $52,5 \%$, dan (5) faktor kemudahan masuk kategori memuaskan dengan $57,5 \%$

C2019 Indonesian Journal of Sport Science and Coaching

\section{ABSTRACT}

Customer satisfaction is very important to increase visitors to the Telaga Ratu swimming pool. Improvement of facilities such as expanding parking lots, increasing the number of bathrooms and water cleanliness are driving customer satisfaction. The purpose of this study was to determine the level of customer satisfaction Telaga Ratu Jambi City swimming pool. This research is a quantitative descriptive survey method with data collection using a questionnaire. The study population was visitors to the Telaga Ratu swimming pool, while the sample in this study used 80 respondents taken by the incidental sampling method. The instrument trial results of 38 statement items, 9 statement items were dropped and 29 items were valid and the reliability was 0.911 calculated with SPSS version 16. The data analysis technique was using descriptive percentage analysis. The results of the study of the level of customer satisfaction 
Telaga Ratu Kota Jambi swimming pool are (1) the product quality factor is in the satisfactory category with a percentage of $76.25 \%$, (2) the price factor is in the satisfactory category with $52.5 \%$, (3) the service quality factor is in. satisfactory category with $81.25 \%$, (4) emotional factors included in the satisfactory category with $52.5 \%$, and (5) convenience factors entered in the satisfactory category with $57.5 \%$

(C)2019 Indonesian Journal of Sport Science and Coaching

\section{PENDAHULUAN}

Olahraga merupakan kata yang sering kita dengar akan tetapi kita sering lupa meluangkan waktu untuk melakukannya. Proses yang dilakukan dalam olahraga pada akhirnya bertujuan pada kebugaran yang prima. Kota Jambi memiliki banyak sekali kolam renang yang mampu dijadikan seabaga fasilitas masyarakat untuk melakukan aktivitas jasmani bahkan sampai rekreasi. Salah satu kolam renang yang ada di Jambi adalah kolam renang Telaga Ratu yang terletak di Jl.Kapt. Sujono No.38, Paal Lima, Jelutung, Kota Jambi. Kolam renang ini dikunjungi oleh keluaraga yang sedang berlibur dengan bermain air didalam kolam renang Telaga Ratu Jambi. Kolam renang yang terkenal di Jambi, memang dikerumuni pengunjung terutama dihari besar seperti hari raya dan ahad (minggu) mengingat bahwa olahraga adalah salah satu kebutuhan demi menjaga kesehatan (Wibowo, 2019; Wibowo \& Sadikin, 2019). Kolam renang Telaga Ratu pada awalnya berfokus pada kolam renang prestasi yang melayani pada umumnya atlet dan anak sekolah. Namun permintaan akan pasar dalam arti masyarakat maka kolam renang telaga ratu mengubah wujudnya atau berinovasi menjadi kolam renang yang dapat dimanfaatkan bagi masyarakat pada umumnya.Terdapat kolam renang bermain bagi anak-anak sehingga kolam renang telaga ratu memiliki daya tarik yang tersendiri. Hal ini dibuktikan dengan banyaknya pengunjung dari masyarakat umum untuk menikmati waktu santainya dikolam renang tersebut. Hal ini juga sangat didukung dengan tarif masuk Rp. 5.000,- sedangkan hari libur dan hari libur nasional Rp. 6.100,-. Tariff yang ditawarkan sangat terjangkau bagi masyarakat menengah kebawah, da didukung juga dengan jam buka yang sangat leluasa yakni Senin : $\quad 08.00-16.00$, Selasa : $\quad 08.00-16.00$, Rabu $\quad 08.00$ 16.00, Kamis :08.00-16.00, Jumat : $\quad$ 08.00-16.00, Sab: 08.00-16.00, Minggu 08.00-16.00 WIB. Kolam renang ini menjadi perhatian penulis dikarenan memang kolam renang ini sangat ramai dikunjungi masyarakat namun secara khusus belum pernah diketahuai data yang resmi tentang tingkat kepuasan masyarakat terhadap kolam renang tersebut. Hal inilah yang membuat penulis berkeinginan untuk melihat secara khusus dan lebih dalam tentang data kepuasan masyarakat melalui sebuah penelitian yang penulis beri judul "Tingkat Kepuasan Masyarakat Terhadap Kolam Renang Telaga Ratu Di Kota Jambi”. Dari semua uraian di atas, kajian yang menarik minat peneliti adalah seberapa besar tingkat kepuasan pelanggan kolam renang Telaga Ratu di Kota Jambi.

\section{METODE PENELITIAN}

\section{A. Prosedur Penelitian}

Penelitian ini adalah penelitian deskriptif kuantitatif dengan menggunakan metode survei dengan teknik angket (kuesioner). Adapun teknik pengambilan data dengan menggunakan angket untuk mengetahui tingkat kepuasan pelanggan kolam renang Telaga Ratu Di Kota Jambi. Menurut Soehardi Sigit (1999: 152) 
penelitian deskriptif merupakan penelitian yang menggambarkan keadaan yang ada menurut kenyataannya. Skor yang diperoleh dari angket kemudian dianalisis dengan analisis deskriptif yang dituangkan dalam bentuk persentase.

\section{B. Populasi dan Sampel Penelitian}

Penelitian ini dengan jumlah sampelnya 80 orang yang diambil dari populasi/pengunjung kolam renang Telaga Ratu dan proses pengambilan data dilaksanakan selama satu minggu. Dengan rincian sebagai berikut: Hari senin diambil 10 sampel, Hari selasa diambil 10 sampel, Hari rabu diambil 10 sampel, Hari kamis diambil 10 sampel, Hari jum'at diambil 10 sampel, Hari sabtu diambil 15 sampel, Hari minggu diambil 15 sampel.

\section{Teknik Pengumpulan Data}

Pengumpulan data ini dilakukan dengan cara membagikan angket penelitian yang telah disiapkan penulis kepada pengunjung kolam renang Telaga Ratu. Penulis akan melakukan analisis terhadap sejumlah angket yang telah terkumpul kembali kepada penulis.

\section{Instrumen Penelitian}

Instrumen penelitian adalah alat atau fasilitas yang digunakan oleh peneliti dalam pengumpulan data agar pekerjaan lebih mudah dan hasilnya baik dalam arti lebih cermat, lengkap dan sistematis, sehingga lebih mudah diolah (Suharsimi Arikunto, 2006: 160). Menurut Sutrisno Hadi (1991: 7) ada tiga langkah yang harus ditempuh dalam menyusun instrumen, yaitu : a. Mendefinisikan Konstrak, b. Menyidik Faktor, c. Menyusun Butir-butir Pertanyaan.

\section{E. Analisis Data}

1. Uji Validitas

Langkah pokok analisis butir soal dalam instrumen angket untuk menentukan kevalidan atau kesahihan instrumen yang disusun mempunyai validitas tinggi: Menghitung korelasi momen takar dengan cara mengkorelasikan skor item pernyataan dengan skor seluruh item. Menggunakan rumus Product Moment. Uji validitas dalam penelitian ini menggunakan bantuan komputer program SPSS versi 16.0 dengan rumus Product Moment dari Karl Pearson.

2. Uji Reliabilitas

Uji keandalan instrumen Menggunakan rumus Alpha Cronbach

\section{F. Teknik Analisis Data}

Analisis data dalam penelitian ini menggunakan teknik deskriptif kuantitatif yang dituangkan dalam bentuk prosentase. Untuk memberikan makna pada skor yang ada, digunakan teknik analisis deskriptif persentase dengan rumus yang digunakan untuk menentukan hasil penelitian ini adalah sebagai berikut (Anas Sudijono, 2000: 43).

$$
\stackrel{\stackrel{f}{\underline{a}}}{P=}{ }_{N} \times 100 \%
$$

Keterangan, P: Persentase, f : Frekuensi, N : Jumlah Sampel

\section{HASIL PENELITIAN DAN PEMBAHASAN}

\section{A. HASIL PENELITIAN}

Kepuasan pelanggan terhadap pelayanan fasilitas kolam renang Telaga Ratu dideskripsikan berdasarkan jawaban pelanggan atas angket-angket yang telah disebarkan. Pendeskripsian data dilakukan dengan mengkategorikan tingkat kepuasan pelanggan kolam renang Telaga Ratu serta pengkategorian tiap-tiap faktor. Tingkat kepuasan pelanggan Kolam renang Telaga Ratu terdiri atas enam faktor.

\section{Kualitas Produk}


Analisis data pada faktor kualitas produk menghasilkan skor minimum sebesar 2,00, maksimal sebesar 3,80, rerata sebesar 3,00 dan standar deviasi (SD) sebesar 0,3. pelayanan kolam renang Telaga Ratu dari faktor kualitas produk adalah memuaskan dengan persentase $76,25 \%$, lalu diikutisangat memuaskan sebesar $15 \%$ dan tidak memuaskan sebesar $8,75 \%$, serta tidak seorang pelanggan pun yang menyatakan sangat tidak memuaskan. Jadi dapat disimpulkan bahwa kepuasan pelanggan kolam renang Telaga Ratu dari faktor kualitas produk masuk dalam kategori memuaskan sebesar 76,25\%. Apabila ditampilkan dalam bentuk grafik dapat dilihat pada gambar di bawah ini :

\section{Harga}

Analisis data pada faktor harga menghasilkan skor minimum sebesar 1,50, maksimum sebesar 3,80, rerata sebesar 2,80 dan standar deviasi (SD) sebesar 0,50. pelayanan kolam renang Telaga Ratu dari faktor harga adalah memuaskan dengan persentase 52,5\%, tidak memuaskan 27,5\%, sangat memuaskan $12,5 \%$ dan sangat tidak memuaskan sebesar 7,5\%. Jadi dapat disimpulkan bahwa sebagian besar pelanggan menyatakan memuaskan dalam faktor harga sebesar 52,5\%.

\section{Kualitas Pelayanan}

Analisis data menghasilkan skor minimum sebesar 1,70, skor maksimum 4,00, rerata sebesar 2,9 dan standar deviasi (SD) sebesar 0,30. pelayanan kolam renang Telaga Ratu dari faktor kualitas pelayanan adalah memuaskan dengan persentase $81,25 \%$, diikuti tidak memuaskan $8,75 \%$, sangat memuaskan $8,75 \%$, serta sangat tidak memuaskan sebesar $1,25 \%$. Jadi dapat disimpulkan bahwa sebagian besar pelanggan kolam renang Telaga Ratu menyatakan faktor kualitas pelayanan masuk kategori memuaskan sebesar $81,25 \%$.

\section{Faktor Emosional}

Analisis data menghasilkan skor minimum sebesar 1,30, skor maksimal sebesar 4,00, rerata sebesar 2,90, standar deviasi (SD) sebesar 0,50. Faktor emosional adalah memuaskan dengan persentase 52,5\%, $27,5 \%$ menyatakan sangat memuaskan, $17,5 \%$ menyatakan tidak memuaskan, dan 2,5\% menyatakan sangat tidak memuaskan. Jadi dapat disimpulkan tingkat kepuasan pelanggan kolam renang Telaga Ratu dari faktor emosional adalah memuaskan sebesar 52,5\%.

\section{Kemudahan}

Analisis data menghasilkan skor minimum sebesar 2,17, skor maksimum sebesar 4,00, rerata sebesar 3,07 dan standar deviasi (SD) sebesar 0,41. Pelayanan kolam renang Telaga Ratu dari faktor kemudahan adalah memuaskan dengan persentase $57,5 \%, 32,5 \%$ menyatakan sangat memuaskan, $10 \%$ menyatakan tidak memuaskan dan 0\% yang menyatakan sangat tidak memuaskan. Jadi dapat disimpulkan tingkat kepuasan pelanggan kolam renang Telaga Ratu dari faktor kemudahan adalah memuaskan sebesar $57,5 \%$.

\section{Keseluruhan}

Berdasarkan analisis di atas, tampak bahwa tingkat kepuasan pelanggan pada tiap faktor yang ada di kolam renang Telaga Ratu berada pada kategori memuaskan dan sangat memuaskan. Secara keseluruhan, hasil analisis terhadap pelayanan kolam renang Telaga Ratu menghasilkan skor minimum sebesar 2,13, skor maksimum sebesar 3,72, rerata sebesar 2,94 dan standar deviasi (SD) sebesar 0,29. Pelayanan kolam renang Telaga Ratu adalah memuaskan dengan persentase $77,5 \%$, diikuti sangat memuaskan sebesar $13,75 \%$, tidak memuaskan sebesar $8,75 \%$, dan tidak seorang pelanggan pun yang menyatakan sangat tidak memuaskan atau $0 \%$. Jadi dapat disimpulkan bahwa pelayanan kolam renang Telaga Ratu secara keseluruhan adalah memuaskan.

\section{B. PEMBAHASAN}

Dari hasil penelitian dapat didefinisikan bahwa tingkat kepuasan pelanggan kolam renang Telaga Ratu sebagian besar masuk kategori memuaskan. Faktor-faktor yang mendukung kesimpulan di atas dijelaskan sebegai berikut:

\section{A. Kualitas Produk}


Berdasarkan hasil yang diperoleh di kolam renang Telaga Ratu mengenai kepuasan pelanggan dari faktor kualitas produk sebagian besar menunjukkan hasil memuaskan yaitu 76,25\%. Hal ini disebabkan karena kolam renang Telaga Ratu memiliki beberapa produk unggulan seperti jumlah kantin yang banyak terdapat di sekitar kolam renang, air yang bersih karena berasal dari mata air yang berada di dasar kolam renang, kondisi peralatan yang disewakan dalam keadaan baik sehingga pengunjung tidak akan merasa takut untuk memakainya.

\section{B. Harga}

Berdasarkan hasil yang diperoleh di kolam renang Telaga Ratu mengenai kepuasan pelanggan dari faktor harga sebagian besar menunjukkan hasil memuaskan yaitu 52,5\%. Komponen harga ini relatif tidak penting bagi mereka yang tidak sensitif terhadap harga. Untuk industry ritel, komponen harga ini sungguh penting dan kontribusinya terhadap kepuasan relatif besar. Hasil ini disebabkan oleh kolam renang Telaga Ratu memiliki harga yang terjangkau meskipun harga tiket masuk lebih tinggi dari pada kolam renang lain, namun kondisi ini diimbangi oleh pengelola kolam renang Telaga Ratu dengan ukuran kolam renang yang luas, harga makanan dan minuman yang cukup terjangkau dan banyaknya pemandangan ikan air tawar yang ada di dalam kolam membuat pengunjung merasa puas. Oleh karena itu pelanggan tidak merasa kecewa, bahkan hasil penelitian ini pun menunjukkan pelanggan merasa puas.

\section{Kualitas Pelayanan}

Berdasarkan hasil yang diperoleh di kolam renang Telaga Ratu mengenai kepuasan pelanggan dari faktor kualitas pelayanan sebagian besar menunjukkan hasil memuaskan yaitu $81,25 \%$. Ada empat unsur pokok dalam konsep ini, yaitu: kecepatan, ketanggapan, keramahan, dan kenyamanan. Ini disebabkan oleh terampilnya petugas kolam renang yang selalu bersiaga di tempatnya masing-masing seperti di loket masuk dan di tempat penyewaan peralatan renang. Dari segi pelayanan terhadap kebutuhan konsumen, kolam renang Telaga Ratu juga mampu memenuhi kebutuhan seperti menyediakan kolam renang khusus anak-anak dan penyewaan peralatan renang seperti kaca mata renang, pipa snorkel, kaki katak dan bahkan peralatan diving pun juga disediakan bagi penggemar diving.

\section{Faktor Emosional}

Berdasarkan hasil yang diperoleh di kolam renang Telaga Ratu mengenai kepuasan pelanggan dari faktor emosional sebagian besar menunjukkan hasil memuaskan yaitu 52,5\%. Ini disebabkan karena ukuran kolam renang yang sangat besar dan bersih sehingga pengunjung akan merasa bebas bermain air di kolam renang. Selain itu pengelola kolam renang Telaga Ratu juga telah mempromosikan kolam renang tersebut menggunakan media sosial sehingga pengunjung dari daerah luar Klaten akan tertarik datang ke kolam renang ini menikmati snorkeling di air tawar tanpa harus ke pantai. Hal inilah yang membuat pelanggan merasa puas.

\section{E. Kemudahan}

Berdasarkan hasil yang diperoleh di kolam renang Telaga Ratu mengenai kepuasan pelanggan dari faktor kemudahan sebagian besar menunjukkan hasil memuaskan yaitu 57,5\%. Ini disebabkan karena sudah banyak petunjuk jalan menuju kolam renang Telaga Ratu baik apa lagi posisi kolam renang di tengah-tengah kota. Selain itu mudahnya menyewa peralatan renang juga menjadi nilai tambah bagi pengelola kolam renang karena para petugas dengan sigap melayani penyewaan peralatan renang. Oleh karena itu pelanggan merasa puas karena sangat mudah menuju lokasi kolam renang dan menyewa peralatan renang.

\section{F. Keseluruhan}

Berdasarkan hasil yang diperoleh di kolam renang Telaga Ratu mengenai kepuasan pelanggan secara keseluruhan sebagian besar menunjukkan hasil memuaskan yaitu 77,5\%. Hal ini disebabkan karena dari faktor kualitas produk, faktor harga, faktor kualitas pelayanan, faktor emosional dan faktor kemudahan kolam renang Telaga Ratu sesuai dengan yang diinginkan dan dibutuhkan pengunjung. Sehingga pelanggan merasa puas akan keberadaan kolam renang Telaga Ratu. 


\section{KESIMPULAN}

Dari hasil analisis data dan pembahasan disimpulkan bahwa sebagian besar kepuasan pelanggan di kolam renang Telaga Ratu masuk kategori memuaskan. Secara rinci kepuasan pelanggan kolam renang Telaga Ratu yaitu: (1) kualitas produk masuk kategori memuaskan dengan persentase $76,25 \%$, (2) harga masuk kategori memuaskan dengan 52,5\%, (3) kualitas pelayanan masuk kategori memuaskan dengan 81,25\%, (4) faktor emosional masuk kategori memuaskan dengan 52,5\%, dan (5) kemudahan masuk kategori memuaskan dengan $57,5 \%$.

\section{DAFTAR PUSTAKA}

Anas Sudijono. (2000). Pengantar Statistik Pendidikan. Jakarta: PT. Raja Grafindo.

Basu Swasta. (1999). Manajemen Pemasaran Modern. Yogyakarta: BPPE (1990). Manajemen Pemasaran Modern. Yogyakarta: Liberty

Danang Sunyoto. (2012). Dasar-Dasar Manajemen Pemasaran. Yogyakarta: CAPS

Fandy Tjiptono. (1996). Strategi Bisnis dan Manajemen. Yogyakarta: Andi Offset

(2000). Manajemen Jasa. Yogyakarta: Andi Offset

Handi Irawan. (2002). 10 Prinsip Kepuasan Pelanggan. Jakarta: PT Elex Media Komputindo

Husein Umar. (2000). "Metodologi Penelitian, Aplikasi dalam Pemasaran”. Jakarta: PT.Gramedia Pustaka Utama

Kotler, Philip. (1997). Manajemen Pemasaran. Jakarta : Prenhallindo

Kotler, Philip \& Garry Amstrong. (2001). Prinsip-prinsip Pemasaran. Jakarta: Erlangga

Kotler, Philip and Amstrong. (1997). Prinsip-prinsip Pemasaran. Jakarta: Erlangga

Wibowo, Y. G. (2019). Managing Sport for Healthy Lifestyle: A Brief Review and Future Research Directions. Indonesian Journal of Sport Science and Coaching, 1(2), 49-57.

Wibowo, Y. G., \& Sadikin, A. (2019). Biology in the 21 st -Century: Transformation in biology science and education in supporting the sustainable development goals. Jurnal Pendidikan Biologi Indonesia, 5(2), 285-296. https://doi.org/10.22219/jpbi.v5i2.7956 